\title{
The medical and social vocation of the French Red Cross
}

\author{
by Dr. Jean Guillermand ${ }^{1}$
}

Seventy-five years ago, soon after the end of the First World War, the history of the Red Cross was at a turning point. In 1919 the National Societies officially joined forces for the first time and extended their mandate to peacetime activities, as defined during a medical conference held in Cannes from 1 to 11 April. The decisions of the Cannes Conference were proposed as guidelines for action by the League of Red Cross Societies which came into existence shortly afterwards, on 5 May. At the same time, the Peace Conference was drawing up the Covenant of the League of Nations. The Cannes Conference was informed on 7 April that the Covenant was to include a provision, Article 25, stating that member nations would "encourage and promote the establishment and co-operation of duly authorized voluntary National Red Cross organizations having as purposes the improvement of health, the prevention of disease and the alleviation of suffering throughout the world".

The three societies which then made up the French Red Cross ${ }^{2}$ were the best prepared to discharge this mandate. After enduring four long years of total war waged on an unprecedented scale, they had naturally enlarged their scope of action to include tasks which went beyond merely helping the wounded. At the end of the conflict, working in the regions that were

\footnotetext{
${ }^{1}$ Pneumo-phthisiologist to the hospitals of the Armed Forces, former administrator of the French Red Cross.

${ }^{2}$ La Société de Secours aux Blessés Militaires (Society for Aid to Wounded Soldiers), set up in 1864, l'Association des Dames francaises (Association of French Ladies), set up in 1881, l'Union des Femmes de France (Frenchwomen's Union), set up in 1884.
} 
liberated as the Allied armies advanced, they even saw their new role supplant some functions of the official Health Service.

There was another reason why they were perfectly well prepared to assume these duties without resorting to improvisation: they had a large number of highly qualified staff who had gained considerable experience in the years since the 1870 Franco-Prussian war. Nurses in particular, who numbered almost 70,000, could offer skills learned from doctors who themselves had profited from the remarkable advances made in medicine as a result of Pasteur's revolutionary work at the end of the nineteenth century.

The decisions made in Cannes thus coincided with a new understanding of the causes of the diseases to be combated and confidence in the efficacy of proven methods, learned during a demanding training course.

For the three French Red Cross societies, this favourable situation was the culmination of a process that reflected both the history of French society and the history of medicine. It could be said that the nursing profession in France still bears its hallmarks; and the pioneer role played by the Red Cross societies is worth examining in the historical perspective befitting anniversaries.

\section{The golden age: $1864-1890$}

The first French relief society, the Société de Secours aux Blessés Militaires (SSBM), dated back to the very creation of the Red Cross in 1864. Under pressure from military circles, it was initially composed solely of men and was geared towards devising and preparing equipment to aid the wounded. The 1870 war revealed both the limits of this approach and the devoted commitment of many women who, despite their inexperience, proved invaluable even when they had to work in makeshift mobile units. On the basis of lessons learned during the conflict, several doctors who had organized such units called publicly for suitable training to be given to these volunteer workers in time of peace.

One such doctor, Auguste Duchaussoy, organizer of the city ambulance service of the sixth arrondissement during the siege of Paris, continued to instruct female ambulance workers after the war. Evening classes held with the help of his colleagues at the Société de Médecine pratique de Paris later took the form of a regular officially recognized training course in April 1877 when an Ecole de garde-malades et d' ambulancières (school for nurses and ambulance attendants) was set up. This was a milestone for the French Red Cross and for the nursing profession: it was 
the first such school to be set up in France, seventeen years after England and Switzerland had taken similar steps. A compilation of the courses given was published for the first time in 1881 .

The training programme was drawn up by doctors with experience in teaching: Duchaussoy, himself a professor at the Paris Faculty of Medicine, gave up his university career to devote himself to the teaching of nurses. The range of skills proposed went far beyond basic knowledge of how to care for the wounded. The instructors set out to impart the fundamental scientific data necessary for an understanding of the acts performed to treat and even prevent.disease. Thus the programme included simplified but precise notions of anatomy, physiology, general pathology, therapeutics and hygiene.

The training course, which ended with a final examination, had to enable nurses to provide efficient services in all circumstances, above and beyond the patriotic duty which was the initial motivation. Right from the beginning, former students, encouraged by Duchaussoy, had used their new skills to support the social services in their local areas.

For administrative reasons (inflexibility of the SSBM statutes), the school could not be attached to the only French Red Cross society in existence at the time. Therefore Duchaussoy decided in 1881 to set up a second Red Cross Society, the Association des Dames françaises (ADF), which was to make teaching a priority.

A few years later, in 1884 , a split occurred which led to the creation of a third Society, the Union des Femmes de France (UFF), which also gave priority to teaching. The UFF's governing body was entirely made up of women, but Dr. Pierre Bouloumié, a former army doctor and a veteran of the siege of Metz, was put in charge of teaching programmes. In the very first year of its existence the UFF also published a training manual for nurses. Somewhat more didactic and more fully illustrated, its successive editions were to become a standard reference work for French nurses.

Finally, the SSBM, which was now recruiting more female members, itself embarked on teaching activities. These started at its Paris headquarters in 1879 under Dr. Aimé Riant and took the form of a series of lectures which gradually became a full programme similar to those run by the other two societies.

Between 1884 and 1886, after the reorganization of the Republican army, the three societies received the official mandate to set up, in peacetime, auxiliary hospitals equipped, staffed and run by their own personnel. Instruction continued with this precise objective in mind, but without overlooking voluntary tasks carried out in peacetime. 


\section{The scientific revolution of the end of the century}

The end of the nineteenth century was marked by rapid progress in medical science thanks to the revolutionary discoveries of Pasteur. The microbes responsible for the suppuration of wounds and for the major infectious diseases were identified between 1877 and 1884. Sterilization of instruments and dressings became standard hospital practice from 1888 with the introduction of Poupinel's dry sterilizer and Rédard's autoclave. This paved the way for aseptic surgery. It began in France in 1890, entailing adaptation of existing surgical units and the setting-up of small, private hospitals and dispensaries especially designed and equipped to use the new techniques. Preparation for surgery and the application of dressings as well as medical treatment had now become a complicated and painstaking matter calling for qualified staff aware of the importance of every aspect of their work.

At the same time, the education of women in general was progressing rapidly, thanks to the Camille See law of 1880 which introduced secondary schooling for girls: in 1886 there were already 35 secondary schools for girls with a total of 6,000 pupils. Many of them were later to become the most willing volunteers within the Red Cross societies. They constituted a trained and receptive audience that was greatly appreciated by medical lecturers.

Thus the most modern ideas about microbes, sterilization and the prevention of infectious diseases were at once included in the highly scientific Red Cross training programme. However, working experience in hospitals was an indispensable adjunct to such training, and places were limited despite the willingness of some public and private establishments to accept student nurses.

\section{Red Cross training broadens its scope}

To remedy this situation, the Red Cross societies set up their own establishments especially designed to provide training, consultations and hospitalization. The first of its kind was opened by the ADF in Auteuil in 1896 (now the Henry Dunant Hospital). The SSBM first set up a training dispensary in the Plaisance, a working-class quarter, and then a model dispensary/teaching hospital in the Place des Peupliers in 1908. The UFF adopted a similar approach when it opened a dispensary/teaching hospital in the Rue de la Jonquière in 1907. By then, the training programme was very comprehensive, even more advanced than the one 
drawn up by the Conseil supérieur de l'Assistance publique in 1899 for public hospitals. Doctors in charge of large hospital departments took over responsibility for training within the Red Cross societies from the general practitioners who had begun the process. They were assisted by several remarkable matrons: Marie Génin who ran the Peupliers school under the authority of Professor Félix Guyon, and Marie Feuillet at the Rue de la Jonquière, under Professor Maurice Letulle.

In addition to the main establishments in Paris with their own hospital units, teaching dispensaries, which were easier to set up, proliferated in the provinces. These not only offered the latest techniques which local committees were keen to provide, but also gave the students an insight into social realities of which they were often unaware. Some trainees even proposed making home visits to follow up patients they had attended in the dispensaries. This spontaneous propensity for social work, which could already be seen in 1878 when Red Cross teaching began and which was an intuitive response to the spirit of the institution, was encouraged by the leaders. It was also part and parcel of teaching philosophy at a time when belief in the power of science kept pace with discoveries which seemed to justify unbounded hopes.

One example of an area in which medical work assumed a social dimension was the tuberculosis control campaign which was then at its height. The tuberculosis dispensaries which were being set up on the basis of the model introduced in Lille by Albert Calmette needed women to conduct surveys in people's homes. In several cities, especially in Lyon, nurses with Red Cross training were recruited for this task.

\section{The Great War}

The 1914-1918 war provided the great testing ground for which the three French Red Cross societies had so patiently prepared. Their contribution towards the Army Health Service was considerable: they set up and ran 730 auxiliary hospitals with a total of 38,000 beds; they sent teams of nurses to accompany troops at the front (mobile surgical units and ambulances for evacuating the wounded); in addition, they ran a large number of infirmaries, railway station canteens and soldiers' clubs.

As the war dragged on, there was a corresponding expansion in social welfare activities in widely diverse fields. With regard to wounded combatants, over and above medical care proper, it became customary to take care of their families and to consider the wounded themselves as charges of the relief society which had been looking after them. The UFF had 
asked its committees in the first year of the war to adopt this policy and issued a reminder at its 1916 General Assembly.

As far as the civilian population was concerned, social work was geared to the most needy, refugees and children in particular. Soup kitchens and milk distributions were organized by all three societies.

Tuberculosis, which had been partly eliminated by the efforts made before the war, was showing an alarming increase among both the military and the civilian population. This recrudescence prompted the Léon Bourgeois law of 15 April 1916; at the height of the war it provided clear guidelines for setting up public health and tuberculosis prevention dispensaries. A Comité national d'assistance aux anciens militaires tuberculeux (National Committee for aid to war veterans with tuberculosis) was established in 1915 and began training nurses to make house calls, organizing specialized instruction intended mainly for qualified Red Cross nurses. In February 1918 the situation was becoming worse; the National Committee launched an appeal to the three Red Cross societies inviting them to take an even more active part in the tuberculosis control campaign by training their own nurses and setting up dispensaries and medical facilities. The appeal did not go unheeded. The Peupliers school offered a specialized teaching course given by Dr. H. Kresser in April and May 1918. There were plans to convert establishments run by the Red Cross for use by tuberculosis patients. However, pressing military needs during the final offensives of the war were to delay by several months large-scale involvement of the Red Cross societies in the tuberculosis control campaign.

\section{The postwar period}

The three societies continued to have to deal with medical and social problems posed by the wounded who were still under treatment and the disabled who were being fitted with prostheses or undergoing rehabilitation. But the scale of physical destruction in the country, the return of refugees, the poor state of health of the population after four years of hardship and the ensuing deadly epidemic of Spanish influenza meant that they had to redouble their efforts. Without waiting for the recommendations of the Peace Conference and of the League of National Societies, the three French societies forged ahead with complementary activities.

Centres providing shelter, food and medical care were established, mainly by the UFF, in the liberated regions. The ADF focused on child care, setting up paediatric centres which provided prenatal consultations, 
infant care and distributions of milk. Holiday camps in the country and observation centres for children at greatest risk from tuberculosis were organized. The SSBM was also active in this area.

At the time the tuberculosis control campaign was a priority for all three societies, which worked closely with the former Comité national d'assistance, which in 1919 became the Comité national de défense contre la tuberculose.

The Committee had already steered them in this direction in February 1918. Their commitment was now total and deemed quite natural by the most highly qualified tuberculosis specialists in France. In a paper on the operation of dispensaries presented during a meeting at the Academy of Medicine on 22 April 1919, Dr. Paul Armand Delille, who had taken part in the Cannes Medical Conference, reiterated the Conference's proposals and had warm words for the professional standards of Red Cross nurses:

"At the moment conditions are particularly favourable for recruiting highly qualified staff, thanks to the presence of numerous Red Cross nurses who, having provided devoted care to our wounded, are now ready to turn their attention to social welfare and public health activities. All that is needed is to provide further training by means of specialized courses".

Pursuant to these recommendations, the three societies encouraged voluntary nurses to enrol in the home visits programme after being given extra training, either at the Peupliers school in the case of the SSBM or at the school set up by the National Committee. Tuberculosis dispensaries meeting the requirements of the 1916 law were established by the three societies, often by converting unoccupied premises. Special care units, observation centres and sanatoriums were also set up throughout France, becoming part of the country's general tuberculosis control campaign.

The teaching provided by the three Red Cross societies reflected the increased scope of their activities. By 1920 the UFF nursing handbook was in its eighth edition and was still a standard reference work, reaching a readership far wider than that for which it was originally intended. Even though the chapter on the management of auxiliary war hospitals had been omitted, the book was considerably expanded, notably to include developments in fields such as infectious diseases like tuberculosis, and dietetics.

It is remarkable that these new tasks which Red Cross nurses were called upon to perform, though evidently less prestigious than taking care of soldiers wounded while defending their fatherland, were embraced with the same enthusiasm. The staff of the three societies continued to increase. 
SSBM nurses numbered 33,925 in $1918,34,367$ in 1919 and 35,564 in 1920. The UFF awarded 365 diplomas in 1919.

Within the nursing profession which was now taking shape, the Red Cross played a particularly important role in the years following the war. The profession's legal standing in France was officially recognized by a decree of 27 June 1922 which instituted a State diploma in the form of a certificate of proficiency awarded according to strict criteria. Representatives of the three societies sat on the Conseil de perfectionnement (proficiency board) established by the decree to draw up the course of study, set official standards for the recognition of schools of nursing and award the first diplomas to candidates whose training was regarded as meeting the new standards. The programme decided upon closely resembled that of the Red Cross schools, which at the time were by far the most experienced. Of the 43 schools approved between 1923 and 1924, fifteen were run by the Red Cross, and of the 1,586 nurses who were awarded the first diplomas during the same period, more than half (823) belonged to the Red Cross.

In the eyes of the public, the association between the Red Cross and nursing went even further: the red cross on nurses' caps came to symbolize the profession itself and not only membership of one of the societies. With the prestige it had gained during the four war years, the Red Cross was seen as a successful combination of technical expertise and devotion to duty. Its presence everywhere and the efficiency of its medical and social work after the war enhanced its prestige even further.

Since that historic moment, the heyday of the French relief societies, the situation has changed. The French Red Cross, formed in 1940 by the merging of the three former societies, still has 35 schools that train between 1,500 and 1,600 nurses per year. It also continues to run a sizeable medical and social welfare service, which is a direct heritage of the activities set up in the aftermath of the First World War.

However, this contribution, albeit important, is a very minor one in relation to France's highly developed medical services today. Red Cross nurses scarcely account for a tenth of the members of a profession which has grown exponentially. Red Cross establishments play a modest but innovative role in a system which itself is very complex and diversified.

Even so, the specific input of the Red Cross remains an asset for the entire system. In the words of Marie Génin, its principal characteristic remains the combination of technical expertise and devotion to duty.

A high level of technical expertise is today a standard requirement and is by no means exclusive to the Red Cross. The predominance of doctors 
in nursing education continues to be a feature of the French system, and sometimes comes in for criticism. For the Red Cross this is a longstanding tradition based on many years of experience.

The humanist element reflects the spirit of the Red Cross even more directly. Just as much as technical training, it implies the ability to take action in all circumstances and to discern with tact and understand what aid is required in difficult situations in a grey area outside the scope of formal teaching, even that of the social sciences.

In its fidelity to its founder, Henry Dunant, this attitude epitomizes the very vocation of the Red Cross. Happily, the French Red Cross is not alone in inheriting this tradition and there is nothing to suggest that it is becoming outdated. On the contrary: at a time when social problems are becoming increasingly complex and the factors contributing to the breakdown of the social order are more difficult to understand and defeat than the effects of microbes, the approach of Dunant's disciples, who help victims without passing any moral judgement, appears to be the most promising way ahead. It is no bad thing that there are still people who uphold this tradition, even though they are in a minority. 